\title{
Guidance on Making Compost from Organic Waste in Jatimukti Village, Jatinangor District, Sumedang Regency, West Java, Indonesia
}

\author{
Mochamad Suyudi ${ }^{\mathbf{a}^{*}}$, Alit Kartiwa ${ }^{\mathbf{b}}$ \\ ${ }^{a, b}$ Department of Statistics, Faculty of Mathematics and Natural Sciences, Universitas Padjadjaran, Bandung, Indonesia \\ *Corresponding author e-mail address: moch.suyudi@gmail.com
}

\begin{abstract}
Compost is a fertilizer that is produced from the decomposition of organic matter by active microorganisms. Jatimukti Village, Jatinangor District, Sumedang Regency is a village that produces a lot of waste. Based on observations, the village looks suitable and has the potential to be introduced to the type of compost as organic material in farmers' gardens. This service aims to foster and direct the people of Jatimukti Village community to have the skills to make compost from organic waste. Community service is carried out through socialization and training on composting. The demonstration of composting is done by using the composting facility that has been prepared. This dedication involves lecturers and students of the Department of Mathematics, Universitas Padjadjaran, as well as the people of Jatimukti Village. The results achieved were made of composters and compost made together, and the ways of making compost by utilizing waste in the community. After being given good and proper waste management training, the community can overcome the surrounding waste problems, and it is hoped that the community can evaluate the management that has been carried out before.
\end{abstract}

Keywords: organic waste, waste management, compost, composter, organic fertilizer.

\section{Introduction}

Waste is a problem that often occurs in Indonesia, even in villages. This is because there are still many Indonesians who are not aware of the impact of waste. Various ways to deal with waste have been done, but it is not done routinely in daily life and is often ignored. As a result, the community will produce waste that has accumulated and pollutes the environment in which they live.

The waste generated and scattered everywhere is certainly dangerous to health, and damaging beauty and comfort. To overcome this problem, community empowerment and direction are needed to manage waste properly. One way that can be done is to convert waste into compost, by recycling organic waste that is increasingly multiplying (Karnchanawong, S. and Nissaikla, 2014). 
Compost is a fertilizer that comes from the process of decomposing organic waste, such as leaves and vegetable residues. Compost can fertilize plants and not use chemicals. Using compost, plants can flourish, and multiply well, because compost is a natural material that does not damage the soil environment. Recycling organic waste into compost has a double benefit, firstly: being able to process waste appropriately, and secondly: by processing waste into compost, commercial profits can be obtained substantially, because compost has a high selling value (Lim et al, 2014).

Converting waste into compost should be done considering the increasing number of waste production in Jatimukti Village every day, thus accelerating the accumulation of waste and causing pollution to the surrounding environment, so it is necessary to work with the Village Head so that villagers are willing to socialize about compost from organic waste and make citizens aware of the effects of littering. It is expected that the Village Head can coordinate with all the Head of the Neighborhood Association (RT) to collect and separate organic waste from inorganic waste so that the waste can be managed properly. Then, the residents process organic waste into compost to produce quality, environmentally friendly, and economical compost fertilizer. Besides, this needs to be implemented in the community, so that people understand the dangers of waste to health. Furthermore, the community is expected to never throw waste again into any place, such as rivers or gutters, because this will damage nature and the ecosystem (Mohee, 2007; Rastogi et al., 2020).

Jatimukti Village, Jatinangor District is also a source of waste, both organic and inorganic which is generally still mixed. This is what often causes problems in the environment, both in quality and quantity. Supposedly with the commencement of sorting activities by the community, then organic waste heaps can be utilized as compost. This service aims to facilitate the people of Jatimukti Village about various knowledge related to composting techniques, from making composter to producing compost (Badar and Qureshi, 2014).

\section{Materials and Methods}

The material used to make compost is organic waste consisting of leaves and the remnants of household vegetables, and a compost maker called a composter. The method of activities undertaken to achieve the objectives of Community Service is the method of lecture, discussion, and consultation. The use of the lecture method is combined with using a laptop and LCD to display PowerPoint material that is equipped with images, including video views of organic waste processing using the composting method.

The demonstration method was chosen to show a work process so that it can provide convenience for trainees. Demonstration for field practice in composter making and composting and at the end of the program evaluation is carried out to see the success of achieving goals.

\section{Results and Discussion}

The implementation of the community service program in Jatimukti Village, Jatinangor District, Sumedang Regency went smoothly and successfully. The service program in the form of training on household waste management with the composting method needs to be continued considering the increasing production of household waste. This was triggered by low public awareness of $3 \mathrm{R}$, which stands for Reuse (reusing used items that can still be used), Reduce (trying to reduce waste), and Recycle (recycling waste to be used). This condition is a consideration for finding the right way to manage waste so that it does not pollute the environment and can provide tangible benefits to the community (productive) (Parkash and Saikia, 2015; Xu and Li, 2017).

To find the right solution to the problem of waste, in this community service, training on organic waste management is made into compost using a composter created by the collaboration between 
lecturers, students, and the community to overcome the presence of organic waste at the household level. The workings of composting organic waste with composter using composter trash cans are as follows.

1) Separate organic and non-organic waste. Organic waste is put into the composter bin.

2) Spray the bioactivation (which has been packaged) input into a spray or bottle that has been given a small hole.

3) Sprinkle sand, soil, or sawdust to prevent $2-3 \mathrm{~cm}$ maggots.

4) Tightly closed the trash, if it has not thrown the waste back again so that it is fully fermented.

5) Trash can be refilled repeatedly as long as it has not entered the maximum period (available in various sizes).

6) During one week of use will release liquid organic fertilizer (POC) can be seen from the hose at the bottom to accommodate the POC.

7) Harvest POC every 2 days until the color turns black.

8) When entering the maximum period (waste is already solid), close 2-3 weeks of the bin and do not refill the waste again. Open the lid to produce compost. Furthermore, the barrel can be used repeatedly as before.

9) For barrels that are 12 months or 120 liters in size, and 24 months 200 liters are available at the side door. Only 6 months of compost can be harvested without waiting for a long time (Lim et al., 2014; Oktiawan et al., 2018).

In the implementation of household waste management by the composting method, the way it works, that is after giving the material, is assisted by the participants by the resource persons. The results of Community Service activities can be seen in broad terms based on the following components.

a) The success of the target number of trainees can be said to be very good, bearing in mind the target number of training participants is 25 people and in the implementation of the activity can be present as many as 27 people, more than 100\%. This is supported by the roles of the Head of the Neighborhood Association (RT), the Head of the Community Unit (RW), and the Village Head starting from the preparation, distribution of invitations, procurement of consumption, places, and equipment.

b) Achievement of the training objectives can be said to be good (75\%), this is due to an increase in knowledge from the participants, at least from what was previously unknown to know and this community service activity has successfully empowered people in Jatimukti Village to process organic waste generated from households into compost by using a self-made composter.

c) The achievement of the planned target material in the Community Service activity can be said to be good $(80 \%)$, because the training material can be delivered as a whole although not in detail because of time constraints. The training materials that have been delivered are environmental concepts, waste classification, community participation in the environment, and household waste management by the composting method.

d) The ability of participants in mastering the material can be said to be sufficient (70\%), this is due to the limited time in the delivery of material using lecture and demonstration methods and supported the ability of different participants to absorb the material presented.

Overall training activities on household waste management by composting are considered successful. This success is measured in addition to the four components above, it can also be seen from the satisfaction of the participants after attending the training activities. The benefits that can be obtained by the training participants, namely understanding the management of household waste by composting methods so that they can participate in protecting the environment and increasing income. 


\section{Conclussion}

Based on the description in the discussion, it can be concluded that the community service activities in Jatimukti Village can increase community knowledge, at least from not knowing to know and successfully empowering the community to process organic waste into compost by composting method. This service program is expected to be continued in the following years in other locations to support environmental sustainability. Besides, it can help improve the family economy.

\section{References}

Badar, R. and Qureshi, S.A. (2014). Composted Rice Husk Improves the Growth and Biochemical Parameters of Sunflower Plants. Journal of Botany, Volume 2014, Article ID 427648, 6 pages.

Karnchanawong, S. and Nissaikla, S. (2014). Effects of Microbial Inoculation on Composting of Household Organic Waste Using Passive Aeration bin. International Journal of Recycl Organic Waste Agricult, (2014) $3: 113-119$.

Lim, L.Y., Chua, L.S., and Lee, C.T. (2014). Effects of Microbial Additive on the Physiochemical and Biological Properties of Oil Palm Empty Fruit Bunches Compost. Journal of Engineering Science and Technology, Special Issue on SOMCHE 2014 \& RSCE 2014 Conference, January (2015), 10-18.

Mohee, R. (2007). Waste Management Opportunities for Rural Communities. Food and Agriculture Organization of the United Nations Rome, 2007.

Oktiawan, W., Hadiwidodo, M., Priyambada, I.B., and Purwono, P. (2018). Decomposition of Food Waste Using Bulking Agent and Bio-Drying Technology. E3S Web of Conferences, 73, 05013 (2018), 1-4.

Pan, I., Dam, B., and Sen, S.K. (2012). Composting of Common Organic Wastes Using Microbial Inoculants. Biotech, (2012) 2:127-134.

Parkash, V. and Saikia, A.J. (2015). Production and Multiplication of Native Compost Fungal Activator by Using Different Substrates and Its Influence on Growth and Development of Capsicum chinensis Jacq. "Bhut Jolokia'”. Biotechnology Research International, Volume 2015, Article ID 481363, 7 pages.

Pengxiang Xu \& Ji Li (2017) Effects of Microbial Inoculant on Physical and Chemical Properties in Pig Manure Composting. Compost Science \& Utilization, 25:sup1, S37-S42.

Rastogi, M., Nandal, M., and Khosla, B. (2020). Microbes as Vital Additives for Solid Waste Composting. Heliyon, 6 (2020) e03343. 